\title{
New Constituent from Podocarpus macrophyllus var. macrophyllus Shows Anti-tyrosinase Effect and Regulates Tyrosinase-Related Proteins and mRNA in Human Epidermal Melanocytes
}

\author{
Kur-Ta Cheng, ${ }^{a}$ Feng-Lin Hsu, ${ }^{b}$ Shih-Hui Chen, ${ }^{c}$ Peng-Ke Hsien, ${ }^{b}$ Hsu-Shan Huang, ${ }^{d}$ \\ Ching-Kuo LeE, ${ }^{b}$ and Mei-Hsien LEE, ${ }^{*}$ \\ ${ }^{a}$ Department of Biochemistry, Taipei Medical University; ${ }^{b}$ Graduate Institute of Pharmacognosy, College of Pharmacy, \\ Taipei Medical University; 250 Wu-Hsing Street, Taipei 110, Taiwan: ${ }^{c} R \&$ D Center, Biotechnology Business Division, \\ Taiyen Biotech Co., Ltd.; No. 13, Zhenxinzuo Neighborhood, Budai Town, Jiayi 625, Taiwan: and ${ }^{d}$ School of Pharmacy, \\ National Defense Medical Center; No. 161, Section 6, Min-Chuan East Road, Taipei 114, Taiwan.
}

Received December 27, 2006; accepted February 16, 2007

A new biflavonoid, 2,3-dihydro-4',4"'-di- $O$-methylamentoflavone (5), and five known compounds, (-)-catechin (1), quercetin (2), 2,3-dihydrosciadopitysin (3), sciadopitysin (4), and isoginkgetin (6), were isolated from Podocarpus macrophyllus var. macrophyllus (Podocarpaceae). These compounds were evaluated their ability to inhibit cellular tyrosinase activity and for their melanin inhibitory activity in human epidermal melanocytes (HEMn). In the melanin synthesis assay, 2,3-dihydro-4', $4^{\prime \prime \prime}$-di- $O$-methylamentoflavone (5) showed a potent antityrosinase effect with $\mathrm{IC}_{50}=0.098 \mathrm{~mm}$ in HEMn. It also significantly decreased both protein and $\mathrm{mRNA}$ levels of the tyrosinase-related protein-2 (TRP-2) by Western blot and quantitative real-time PCR (qRT-PCR) analysis. These findings suggest that the new compound, 2,3-dihydro-4', $4^{\prime \prime \prime}-$ di- $O$-methylamentoflavone (5), is the most active component of $P$. macrophyllus var. macrophyllus in inhibiting pigmentation and that this inhibition is exerted through inhibition of transcription of the genes encoding TRP2.

Key words 2,3-dihydro-4', $4^{\prime \prime \prime}$-di- $O$-methylamentoflavone; human epidermal melanocyte; tyrosinase; tyrosinase-related protein2; quantitative real-time PCR

Pigmentation due to the synthesis and dispersion of melanin protects the skin from harmful effects of sunlight, ${ }^{1)}$ but unwanted hyperpigmentation can also produce a significant psychological stress. The development of effective therapeutics to modulate skin pigmentation has been slow owing to the complexity of molecular mechanisms regulating pigmentation. ${ }^{2}$ Our laboratory has determined that certain natural products inhibit tyrosinase, the key and the rate-limiting enzyme in the biosynthesis of melanin in pigmented cells of humans and animals. ${ }^{3)}$ Tyrosinase (EC 1.14.18.1) is a monophenol or $o$-diphenol oxidoreductase. It is also known as polyphenol oxidase (PPO). This enzyme is a bifunctional copper-containing enzyme present in microorganisms, plants, and animals. ${ }^{4)}$ It catalyzes two distinct reactions of melanin synthesis: the hydroxylation of tyrosine to 3,4-dihydroxyphenylalanine (DOPA) and the oxidation of DOPA to dopaquinone. ${ }^{5)}$ After spontaneous conversion of dopaquinone to dopachrome, dopachrome tautomerase (tyrosinase-related protein-2, DCT/TRP-2) catalyzes the conversion of dopachrome to 5,6-dihydroxyindole-2-carboxylic acid (DHICA). Subsequently, the oxidative polymerization of DHICA is catalyzed by DHICA oxidase (tyrosinase-related protein-1, TRP-1). ${ }^{6}$ In mammals, melanin production is restricted to the melanocytes of the skin, hair follicles, and pigment epithelium in the retina. Three melanocyte-specific enzymes, tyrosinase, TRP-1, and TRP-2 are involved in melanogenesis, in which tyrosine is converted into melanin pigments. ${ }^{7)}$ The tyrosinase-related proteins, TRP-1 and TRP-2, catalyze distal steps that control the type of melanin produced. ${ }^{8,9)}$ Tyrosinase inhibitors may be potential skin whitening agents in the development of medical and cosmetic products against hyperpigmentation. ${ }^{10)}$

Podocarpaceae are mainly distributed in the Southern hemisphere, such as South America and Australia, and in parts of the Northern hemisphere, including southeastern China, Taiwan, Japan, and the Philippines. Podocarpus macrophyllus (ThunB.) SweEt var. macrophyllus grows in Taiwan, southeastern China, and Japan, and is usually used as courtyard plant because of its beautiful shape. Conifers have evolved constitutive and inducible defense mechanisms for wound healing and against the attack of bark beetles and other organisms. ${ }^{11)}$ Previous investigation of Podocarpus species afforded flavonoids, diterpenoids, and steroids. ${ }^{12-17)}$ An ethanolic extract of $P$. neriifolius showed antiproliferative activity against two major tumor cell lines. ${ }^{18)}$ There is no published study of the constituents of P. macrophyllus var. macrophyllus and its related activities. In the present study, we evaluated the effect of constituents from this plant on free radical and melanin synthesis in human epidermal melanocytes (HEMn) using Western blot analysis of tyrosinase-related proteins and quantitative real-time PCR.

\section{Results and Discussion}

The $80 \%$ aqueous $\mathrm{MeOH}$ extract of P. macrophyllus var. macrophyllus was fractionated with EtOAc. The two fractions were chromatographed over Diaion HP 20, ODS, and Sephadex LH-20 columns, then purified by reverse-phase HPLC to yield six compounds. The structures of the known compounds were elucidated by comparing their physical properties with reported data. Compounds $\mathbf{1}-\mathbf{6}$ were characterized as $(-)$-catechin $(\mathbf{1}),{ }^{19)}$ quercetin $(\mathbf{2}),{ }^{20)}$ 2,3-dihydrosciadopitysin (3), ${ }^{21)}$ sciadopitysin (4), ${ }^{22)}$ the new amentoflavone derivative (5), and isoginkgetin (6) (Fig. 1). ${ }^{23)}$

Compound $\mathbf{5}$ was obtained as a pale-yellow powder. The HR-FAB-MS displayed a quasi-molecular ion at $\mathrm{m} / \mathrm{z}$ $569.1436[\mathrm{M}+\mathrm{H}]^{+}$suggesting a molecular formula of 
<smiles>Oc1cc(O)c2c(c1)OC(c1ccc(O)c(O)c1)C[C@@H]2O</smiles><smiles>O=c1cc(-c2ccc(O)c(O)c2)oc2cc(O)cc(O)c12</smiles>
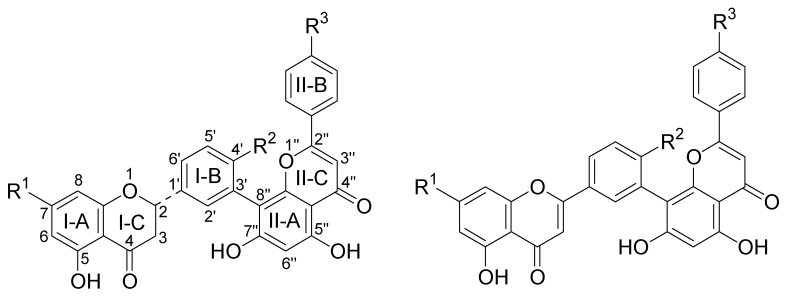

3: $\mathrm{R}^{1}=\mathrm{R}^{2}=\mathrm{R}^{3}=\mathrm{OCH}_{3}$ 5: $\mathrm{R}^{1}=\mathrm{OH}, \mathrm{R}^{2}=\mathrm{R}^{3}=\mathrm{OCH}_{3}$

4: $\mathrm{R}^{1}=\mathrm{R}^{2}=\mathrm{R}^{3}=\mathrm{OCH}_{3}$ 6: $\mathrm{R}^{1}=\mathrm{OH}, \mathrm{R}^{2}=\mathrm{R}^{3}=\mathrm{OCH}_{3}$

Fig. 1. The Structures of the Isolated Compounds from P. macrophyllus var. macrophyllus

$\mathrm{C}_{32} \mathrm{H}_{24} \mathrm{O}_{10}$. The UV spectrum of compound $\mathbf{5}$ exhibited absorption maxima at $370 \mathrm{~nm}$ and $265 \mathrm{~nm}$. In the ${ }^{1} \mathrm{H}-\mathrm{NMR}$ spectrum of compound 5, two chelated hydroxyl groups had resonances at $\delta 12.16(1 \mathrm{H}$, br s) and $13.08(1 \mathrm{H}$, br s) and two $O$-methyl groups had resonances at $\delta 3.78$ and 3.85 (each $3 \mathrm{H}, \mathrm{s}$ ). The resonances at $\delta 5.94$ and 5.97 (each $1 \mathrm{H}$, brs) were ascribable to H-6 and H- 8 on the I-A ring, respectively, those at $\delta 5.57(1 \mathrm{H}, \mathrm{dd}, J=2.6,12.8 \mathrm{~Hz}, \mathrm{H}-2), 3.27(1 \mathrm{H}, \mathrm{m}$, $\mathrm{H}-3 \mathrm{a}), 2.81(1 \mathrm{H}, \mathrm{m}, \mathrm{H}-3 \mathrm{~b})$ arose from the $\mathrm{I}-\mathrm{C}$ ring, and the ${ }^{13} \mathrm{C}-\mathrm{NMR}$ resonances at $\delta 79.4(\mathrm{~d}, \mathrm{C}-2)$ and $43.2(\mathrm{t}, \mathrm{C}-3)$ indicated the presence of a flavanone unit. ${ }^{24)}$ Furthermore, the flavone unit in compound $\mathbf{5}$ was similar to that in compound $3^{21)}$ on the basis of resonances observed at $\delta 6.67(1 \mathrm{H}, \mathrm{s}, \mathrm{H}-$ $\left.3^{\prime \prime}\right)$ and $6.41\left(1 \mathrm{H}, \mathrm{s}, \mathrm{H}-6^{\prime \prime}\right)$, as well as on $\mathrm{AA}^{\prime} \mathrm{XX}^{\prime}$ system resonances at $\delta 7.67\left(2 \mathrm{H}, \mathrm{d}, J=8.7 \mathrm{~Hz}, \mathrm{H}-2^{\prime \prime \prime}\right.$ and $\left.\mathrm{H}-6^{\prime \prime \prime}\right)$ and $6.98\left(2 \mathrm{H}, \mathrm{d}, J=8.7 \mathrm{~Hz}, \mathrm{H}-3^{\prime \prime \prime}\right.$ and $\left.\mathrm{H}-5^{\prime \prime \prime}\right)$. The characteristics of the ${ }^{13} \mathrm{C}$-NMR spectrum of compound 5 (Table 1) were similar to those of biflavonoids $\mathbf{3}, \mathbf{4}$, and $\mathbf{6}$. Thus, compound 5 was composed of a flavanone and a flavone unit. Two $O$ methyl groups $\left[\delta_{\mathrm{H}} 3.78\right.$ and 3.85 (each $3 \mathrm{H}, \mathrm{s}$ ), $\delta_{\mathrm{C}} 55.5$ and 55.6, respectively] in compound 5 linked to C-4' and C-4"', respectively, were revealed by the $\mathrm{HMBC}$ spectrum. The linkage between $\mathrm{C}-3^{\prime}$ of the flavanone unit and $\mathrm{C}-8^{\prime \prime}$ of the flavone unit was confirmed by HMBC and NOESY spectra. The HMBC spectrum demonstrated that $\mathrm{H}-2^{\prime}[\delta 7.62(1 \mathrm{H}, \mathrm{d}$, $J=1.6 \mathrm{~Hz})]$ was related to $\mathrm{C}-2(\delta 79.4)$ and $\mathrm{C}-8^{\prime \prime}(\delta 104.8)$ and that $\mathrm{H}-6^{\prime \prime}[\delta 6.41(1 \mathrm{H}, \mathrm{s})]$ was related to $\mathrm{C}-5^{\prime \prime}(\delta 162.0)$, $\mathrm{C}-8^{\prime \prime}(\delta 104.8)$ and $\mathrm{C}-10^{\prime \prime}(\delta$ 105.2). The heteronuclear correlations further established the constitution of compound 5 : H-2/C-1', H-2/C-6', H-3a/C-4, H-3b/C-4, H-6/C-5, H-6/C-7, H-6/C-10, H-8/C-6, H-8/C-7, H-8/C-9, H-8/C-10, H-5'/C-3', $\mathrm{H}-5^{\prime} / \mathrm{C}-4^{\prime}, \mathrm{H}-6^{\prime} / \mathrm{C}-2, \mathrm{H}-6^{\prime} / \mathrm{C}-4^{\prime}, \mathrm{H}-3^{\prime \prime} / \mathrm{C}-2^{\prime \prime}, \mathrm{H}-3^{\prime \prime} / \mathrm{C}-4^{\prime \prime}, \mathrm{H}-$ $3^{\prime \prime} / \mathrm{C}-10^{\prime \prime}, \mathrm{H}-3^{\prime \prime} / \mathrm{C}-1^{\prime \prime \prime}, \quad \mathrm{CH}_{3} \mathrm{O}-4^{\prime} / \mathrm{C}-4^{\prime}$, and $\mathrm{CH}_{3} \mathrm{O}-4^{\prime \prime \prime} / \mathrm{C}-4^{\prime \prime \prime}$ (Fig. 2). The NOESY experiment showed the correlation between $\mathrm{H}-2$ and $\mathrm{H}-3, \mathrm{H}-2$ and $\mathrm{H}-2^{\prime}, \mathrm{H}-2$ and $\mathrm{H}-6^{\prime}, \mathrm{H}-3$ and $\mathrm{H}-$ $2^{\prime}, \mathrm{H}-5^{\prime}$ and $\mathrm{H}-6^{\prime}$, as well as $\mathrm{H}-5^{\prime}$ and $-\mathrm{OMe}$ for the flavanone unit. For the other flavone unit, H-3" was correlated with H-2"', H-2"' with H-3"', and H-3"' with -OMe. The coupling constant of $\mathrm{H}-2(J=2.6,12.8 \mathrm{~Hz})$ indicated the equato-

Table 1. The ${ }^{1} \mathrm{H}-(500 \mathrm{MHz})$ and ${ }^{13} \mathrm{C}-\mathrm{NMR}(125 \mathrm{MHz})$ Data for 2,3-Dihydro-4', $4^{\prime \prime \prime}$-di-O-methylamentoflavone (5) $\left(\mathrm{Me}_{2} \mathrm{CO}-d_{6}\right)$

\begin{tabular}{|c|c|c|}
\hline Position & $\delta_{\mathrm{C}}(\mathrm{ppm})^{a)}$ & $\delta_{\mathrm{H}}$, multi $(J$ in $\mathrm{Hz})$ \\
\hline 2 & 79.4 & $5.57, \mathrm{dd}(2.6,12.8)$ \\
\hline \multirow[t]{2}{*}{3} & 43.2 & $2.81, \mathrm{~m}$ \\
\hline & & $3.27, \mathrm{~m}$ \\
\hline 4 & 196.5 & \\
\hline 5 & 163.9 & \\
\hline 6 & 96.4 & 5.94 , br s \\
\hline 7 & 167.1 & \\
\hline 8 & 95.5 & $5.97, \mathrm{brs}$ \\
\hline 9 & 163.1 & \\
\hline 10 & 102.6 & \\
\hline $1^{\prime}$ & 131.6 & \\
\hline $2^{\prime}$ & 131.9 & $7.62, \mathrm{~d}(1.6)$ \\
\hline $3^{\prime}$ & 121.4 & \\
\hline $4^{\prime}$ & 158.7 & \\
\hline $5^{\prime}$ & 111.7 & $7.23, \mathrm{~d}(8.4)$ \\
\hline $6^{\prime}$ & 128.4 & $7.65, \mathrm{dd}(1.6,8.4)$ \\
\hline $2^{\prime \prime}$ & 164.6 & \\
\hline $3^{\prime \prime}$ & 103.5 & $6.67, \mathrm{~s}$ \\
\hline $4^{\prime \prime}$ & 182.9 & \\
\hline $5^{\prime \prime}$ & 162.0 & \\
\hline $6^{\prime \prime}$ & 99.1 & $6.41, \mathrm{~s}$ \\
\hline $7^{\prime \prime}$ & 161.6 & \\
\hline $8^{\prime \prime}$ & 104.8 & \\
\hline $9^{\prime \prime}$ & 155.2 & \\
\hline $10^{\prime \prime}$ & 105.2 & \\
\hline $1^{\prime \prime \prime}$ & 123.8 & \\
\hline $2^{\prime \prime \prime}$ & 128.4 & $7.67, \mathrm{~d}(8.7)$ \\
\hline $3^{\prime \prime \prime}$ & 114.8 & $6.98, \mathrm{~d}(8.7)$ \\
\hline $4^{\prime \prime \prime}$ & 163.9 & \\
\hline $5^{\prime \prime \prime}$ & 114.8 & $6.98, d(8.7)$ \\
\hline $6^{\prime \prime \prime}$ & 128.4 & $7.67, \mathrm{~d}(8.7)$ \\
\hline $4^{\prime}-\mathrm{OCH}_{3}$ & 55.5 & $3.78, \mathrm{~s}$ \\
\hline $4^{\prime \prime \prime}-\mathrm{OCH}_{3}$ & 55.6 & $3.85, \mathrm{~s}$ \\
\hline
\end{tabular}

a) The data were confirmed by COSY, HMQC, and HMBC experiment.

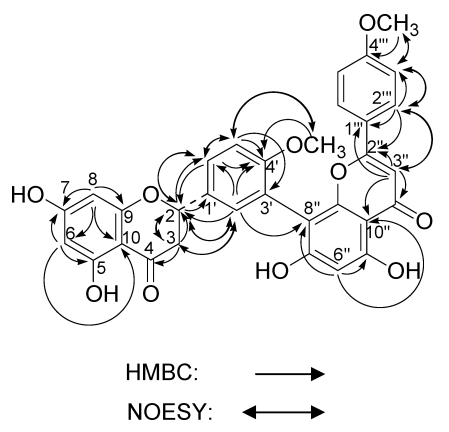

Fig. 2. Key HMBC and NOESY Observed in 2,3-Dihydro-4',4"'-di-Omethylamentoflavone (5)

rial location of aryl group on C-2 and was further confirmed by comparing the $\mathrm{CD}$ spectrum with literature values for flavanones. $^{25)}$ It showed a positive Cotton effect at $328 \mathrm{~nm}$ $\left(n \rightarrow \pi^{*}\right)$ and a negative Cotton effect near $292 \mathrm{~nm}\left(\pi \rightarrow \pi^{*}\right)$. Thus, compound $\mathbf{5}$ with a $2 S$ configuration exhibited a conformation with a $\mathrm{C}-2$ equatorial aryl group. ${ }^{25)}$ Accordingly, compound 5 was determined to be 2,3-dihydro- $4^{\prime}, 4^{\prime \prime \prime}$-di- $O$ methylamentoflavone (Fig. 2). To our knowledge, this is the first reported isolation of 2,3-dihydrobiflavones, biflavones, and flavones from P. macrophyllus var. macrophyllus.

The Effects of Anti-tyrosinase Activities and Melanin Inhibition of the Isolated Constituents in HEMn Cells Tyrosinase activity is involved in the formation of melanin 


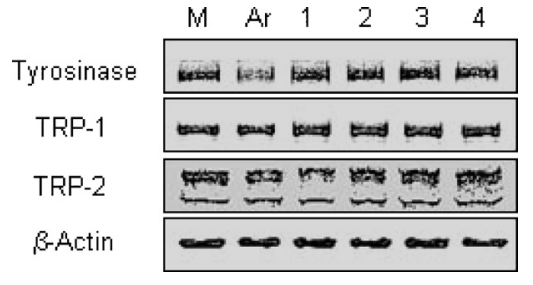

Fig. 3. Expression of Tyrosinase-Related Proteins in 2,3-Dihydro-4', $4^{\prime \prime \prime}$ di-O-methylamentoflavone (5)-Treated HEMn

Cultured melanocytes were treated with medium or test compounds for $24 \mathrm{~h}$. Cells were then harvested and lysates (equal amount proteins) were subjected to polyacrylamide gel electrophoresis, followed by electroblotting and immunostaining with antibodies to tyrosinase, TRP-1, and TRP-2. M: medium only, Ar: arbutin at $2.5 \mathrm{~mm}, 1:(5)$ at $0.1 \mathrm{~mm}, 2:(\mathbf{5})$ at $0.08 \mathrm{~mm}, 3:(5)$ at $0.06 \mathrm{~mm}, 4:(5)$ at $0.04 \mathrm{~mm}$.

Table 2. Cellular Tyrosinase and Melanin Synthesis Inhibition in HEMn Cells

\begin{tabular}{cccc}
\hline \hline \multirow{2}{*}{ Compound } & $\begin{array}{c}\text { Cell viability } \\
{[100 \mu \mathrm{M}]}\end{array}$ & \multicolumn{2}{c}{ Inhibition \pm S.D. $(\%)[100 \mu \mathrm{M}]$} \\
\cline { 3 - 4 } & & Tyrosinase $^{a)}$ & Melanin \\
\hline $\mathbf{1}$ & $89.74 \pm 8.36$ & $25.88 \pm 0.22$ & $0.48 \pm 4.76$ \\
$\mathbf{2}$ & $71.60 \pm 7.59$ & n.t. & n.t. \\
$\mathbf{3}$ & $60.94 \pm 7.84$ & n.t. & n.t. \\
$\mathbf{4}$ & $71.92 \pm 5.37$ & n.t. & n.t. \\
$\mathbf{5}$ & $89.90 \pm 7.94$ & $53.22 \pm 1.05$ & $17.26 \pm 2.53$ \\
$\mathbf{6}$ & $86.16 \pm 7.40$ & $36.84 \pm 0.44$ & $6.73 \pm 3.47$ \\
\hline
\end{tabular}

a) $\mathrm{The}_{\mathrm{IC}}$ value of the positive control, arbutin, was $3.0 \mathrm{~mm}^{27)}$ n.t.: not tested.

pigments. ${ }^{26)}$ Compounds exhibiting tyrosinase inhibitory effects may reduce melanin biosynthesis and may find some applications in cosmetic products. In the present study, each isolated component was evaluated for its effect on the cell viability of HEMn cells. When the concentration was $100 \mu \mathrm{M}$, (-)-catechin (1), 2,3-dihydro-4', $4^{\prime \prime \prime}$-di- $O$-methylamentoflavone (5), and isoginkgetin (6) showed less toxicity in HEMn cells ( $>80 \%$ viability) (Table 2$)$. We further tested the inhibitory activities of the three compounds on cellular tyrosinase. Of these three, 2,3-dihydro-4',4"'-di- $O$-methylamentoflavone (5) was the most potent inhibitor of tyrosinase at $0.1 \mathrm{~mm}$ (53.2\% inhibition). The extent of reduction in melanin content following treatment with these substances varied with the component. 2,3-Dihydro-4',4"'-di- $O$-methylamentoflavone (5) also showed the most effect (Table 2). Its tyrosinase inhibition was shown in the concentration-dependent manner ranging from 0.04 to $0.1 \mathrm{~mm}$, and its $\mathrm{IC}_{50}$ was $0.098 \mathrm{~mm}$ (compare with the positive control arbutin [ $\mathrm{IC}_{50}$ $3.0 \mathrm{~mm}$. $^{27)}$

Besides tyrosinase, two tyrosinase-related proteins, TRP-1 and TRP-2, have been characterized and shown to catalyze specific reactions in melanin synthesis. The effect of 2,3-dihydro-4', $4^{\prime \prime \prime}$-di- $O$-methylamentoflavone (5) on the expression of these tyrosinase-related proteins was evaluated by Western blotting. Treatment with various concentrations $(0.04 \mathrm{mM}$, $0.05 \mathrm{~mm}, 0.06 \mathrm{~mm}$, and $0.1 \mathrm{~mm}$ ) for $24 \mathrm{~h}$ did not noticeably influence the expression TYR and TRP-1 proteins but strongly inhibited the expression of TRP-2 protein (Fig. 3). Tyrosinase is the key enzyme in pigment synthesis. The essential function of tyrosinase in melanin biosynthesis has been known for many decades; in the absence of functional tyrosinase, there most certainly would not be any synthesis of melanin in mammalian melanocytes. ${ }^{9)}$ TRP-1 was reported to

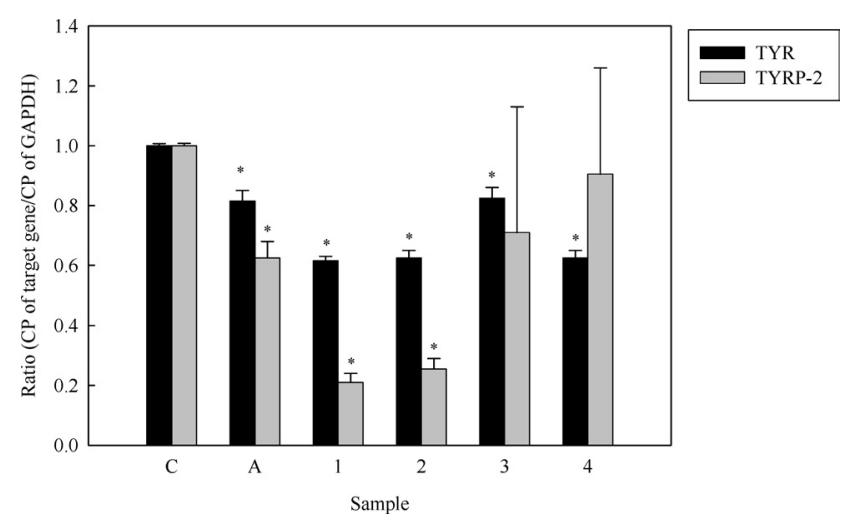

Fig. 4. Expression of TYR and TYRP2 mRNAs in 2,3-Dihydro-4',4"'-di$O$-methylamentoflavone (5)-Treated HEMn

Cultured melanocytes were treated with medium or test compounds for $24 \mathrm{~h}$. TYR and TYRP2 mRNA expression was normalized to the expression of GAPDH mRNA. Measurements were conducted in triplicate, and mean expression values for test samples relative to mean expression values for negative controls are indicated. C: medium only, A: arbutin at $2.5 \mathrm{~mm}, 1:(5)$ at $0.1 \mathrm{~mm}, 2:(5)$ at $0.08 \mathrm{~mm}, 3:(5)$ at $0.06 \mathrm{~mm}, 4:(5)$ at $0.04 \mathrm{~mm}$. Statistical significance $(p$-value $<0.05$ ) was tested using the non-parametric Mann-Whitney $U$-test.

play an important role in the stabilization of tyrosinase, to be involved in the maintenance of melanosome ultrastructure, and to affect melanocyte proliferation, morphology, and melanocyte cell death. ${ }^{28-30)} 2,3$-Dihydro-4', $4^{\prime \prime \prime}$-di- $O$-methylamentoflavone (5) did not noticeably affect these two proteins (TYR and TRP-1) in the pigment synthesis pathway. TRP-2 is responsible for the conversion of the intermediate eumelanin compound dopachrome to DHICA. The presence of TRP-2 is thought to affect the cytotoxicity of melanogenic intermediates in the pigment synthetic pathway of melanocytes. $^{31)}$ TRP-2 also appears to be specifically associated with the resistance of human melanomas to DNA damaging drugs and radiation treatment. ${ }^{32)}$ Therefore, 2,3-dihydro-4', $4^{\prime \prime \prime}$-di- $O$-methylamentoflavone (5) is believed to affect the cytotoxicity of melanogenic intermediates in melanocytes, ${ }^{33)}$ which may therefore reduce pigment production.

The pigment-related gene expression of this compound was also evaluated. The human genes encoding the TRPs are often termed TYRPs because of the apparent similarity of human DCT/TRP-2 protein to tyrosinase. 2,3-Dihydro- $4^{\prime}, 4^{\prime \prime \prime}$ di-O-methylamentoflavone (5) showed inhibitory activities on tyrosinase-related proteins levels, TYR and TRP-2. To determine whether TYR and TYRP2 expression was affected by 5 at the transcriptional level, the expression of TYR and TYRP2 mRNAs was measured in 5-treated cells using qRTPCR. GAPDH was served as a housekeeping gene. Levels of mRNAs encoding tyrosinase and TRP-2 were found to be down-regulated by $\mathbf{5}$. Compared to the untreated control values, expression was decreased by $0.375-, 0.175-, 0.375-$, and 0.385 -fold for the TYR gene and by $0.095-, 0.29-, 0.745-$, and 0.79 -fold for the TYRP2 gene at concentrations of 0.04 , $0.06,0.05$, and $0.1 \mathrm{~mm}$ of 5 , respectively (Fig. 4). Thus, the decrease in mRNA expression was dose-dependent for TYRP2 mRNA, but not dose-dependent for TYR mRNA. In the melanin synthesis, $\mathbf{5}$ affected both mRNA and protein levels of the TYRP2. Nevertheless, $\mathbf{5}$ only slightly influenced in the mRNA level of TYR without affecting in the protein level. In summary, six phenolic compounds, including the new 2,3-dihydro-4', 4'"-di- $O$-methylamentoflavone (5), have 
been isolated from $P$. macrophyllus var. macrophyllus for the first time. These six compounds had different cellular tyrosinase inhibitory activities. Among these compounds, 2,3-dihydro-4', $4^{\prime \prime \prime}$-di- $O$-methylamentoflavone (5) had the downregulated the protein and mRNA expression of the pigmentrelated enzymes, tyrosinase and TRP-2. Thus, this compound is the most attractive of the six candidate additives for the cosmetic products.

\section{Experimental}

Materials Arbutin, HEPES buffer, 6-hydroxy-2,5,7,8-tetramethylchroman-2-carboxylic acid (Trolox), 3-(4,5-dimethyl-thiazol-2-yl)-2,5-diphenyltetrazolium bromide (MTT), DOPA, phosphate-buffered saline (PBS), and phenylmethylsulfonyl fluoride (PMSF) were purchased from Sigma-Aldrich Chemical Co. (St. Louis, MO, U.S.A.). The other chemicals or reagents used in the study were high-grade commercial products.

Plant Material The leaves of P. macrophyllus var. macrophyllus were collected in August 2003 in Taipei, and identified by Dr. Kur-Ta Cheng, Department of Biochemistry, Taipei Medical University, Taiwan. A voucher specimen (M-63) is deposited at the Graduate Institute of Pharmacognosy, College of Pharmacy,Taipei Medical University, Taipei, Taiwan.

General Experimental ${ }^{1} \mathrm{H}$ - and ${ }^{13} \mathrm{C}-\mathrm{NMR}$ spectra were recorded on a Bruker DRX-500 MHz $\left({ }^{1} \mathrm{H}\right.$ at $500 \mathrm{MHz} ;{ }^{13} \mathrm{C}$ at $\left.125 \mathrm{MHz}\right)$, and chemical shifts were given in $\delta(\mathrm{ppm})$ with TMS as an internal standard. 2-D spectra were determined by ${ }^{1} \mathrm{H}-{ }^{1} \mathrm{H}$ COSY, HMQC, HMBC, and NOESY experiments. Optical rotation was measured on a JASCO P-1020 polarimeter (Tokyo, Japan). HPLC was carried out with a Hitachi L-7100 pump and an L-7420 UV-VIS detector with a reversed phase column (Biosil ODS-W, $4.6 \mathrm{~mm} \times 250 \mathrm{~mm}, 10 \mathrm{~mm} \times 250 \mathrm{~mm}$, Biotic Chemical, Taipei, Taiwan). UV spectra were recorded on a UV-1601 (Shimadzu, Tokyo, Japan) spectrophotometer. All solvents were distilled before use. Solvents were removed from the extracts by rotary evaporator under reduced pressure at temperatures up to $40^{\circ} \mathrm{C}$. TLC was performed on silica gel (Kieselgel $60 \mathrm{~F}_{254}$, Merck, Darmstadt, Germany).

Extraction and Isolation The fresh leaves of $P$. macrophyllus var. macrophyllus $(8 \mathrm{~kg})$ were homogenized in $80 \% \mathrm{MeOH}(\times 3)$ at room temperature. After filtering and concentrating under reduced pressure, the $80 \%$ $\mathrm{MeOH}$ extract was obtained. A suspension of the $80 \% \mathrm{MeOH}$ extract in $\mathrm{H}_{2} \mathrm{O}$ was partitioned with EtOAc to give EtOAc and aqueous fractions. The aqueous fraction was subjected to chromatographic separation over Diaion HP 20 and eluted with increasing $\mathrm{MeOH}$ concentration to give seven fractions (Frs. 1 to 7). Fr. 2 was rechromatographed over Sephadex LH-20 with $30 \%$ $\mathrm{MeOH}$ and then purified by semi-preparative HPLC using $15 \% \mathrm{MeCN}$ to yield compound $\mathbf{1}(13.2 \mathrm{mg})$. Fr. 7 was further purified by semi-preparative HPLC eluting with $80 \% \mathrm{MeOH}$ to give compound $2(12 \mathrm{mg})$. The EtOAc layer was subjected to chromatographic separation over Sephadex LH-20 and eluted with $\mathrm{MeOH}$ to give six fractions (EA-Frs. 1 to 6) corresponding to the TLC results. EA-Fr. 3 was further chromatographed over an MCI CHP20P column with $80 \% \mathrm{MeCN}$ and then purified by semi-preparative HPLC eluting with $65 \% \mathrm{MeCN}$ to give compound $3(6.5 \mathrm{mg})$. EA-Fr. 4 was purified by semi-preparative HPLC eluting with $65 \% \mathrm{MeCN}$ to give compound $4(7.3 \mathrm{mg})$. EA-Fr. 5 was rechromatographed over Sephadex LH-20 column with $100 \% \mathrm{MeOH}$ and then purified by semi-preparative HPLC eluting with $65 \% \mathrm{MeCN}$ to give compounds $5(3.2 \mathrm{mg})$ and $6(4.3 \mathrm{mg})$, respectively.

$(-)$-Catechin (1): A pale-yellow power, $\mathrm{mp} 176^{\circ} \mathrm{C} .[\alpha]_{\mathrm{D}}^{25}-42.5^{\circ}(c=0.5$, $\mathrm{MeOH})$. The spectral data were compared with the literature. ${ }^{19)}$

Quercetin (2): A yellow power, mp $315^{\circ} \mathrm{C}$. FAB-MS $m / z 303[\mathrm{M}+\mathrm{H}]^{+}$. The physical and spectral data were compared with an authentic sample and published data. $^{20)}$

2,3-Dihydrosciadopitysin (3): A amorphous power, ESI-MS $\mathrm{m} / \mathrm{z} 583.3$ $[\mathrm{M}+\mathrm{H}]^{+}$. The spectral data were compared with the published data. ${ }^{21)}$

Sciadopitysin (4): A pale-yellow power, ESI-MS $m / z 581.3[\mathrm{M}+\mathrm{H}]^{+}$. The spectral data were compared with the published data. ${ }^{22)}$

2,3-Dihydro-4', $4^{\prime \prime \prime}$-di- $O$-methylamentoflavone (5): A pale-yellow power, $[\alpha]_{\mathrm{D}}^{25}-10^{\circ}(c=0.1, \mathrm{MeOH})$. UV $\lambda_{\max }(\mathrm{EtOH}) \mathrm{nm}(\varepsilon): 280(89125), 322$ (50119). CD [MeOH, nm, $\Delta \varepsilon$ ]: $292(-4.22), 328(+1.51) .{ }^{1} \mathrm{H}-,{ }^{13} \mathrm{C}-\mathrm{NMR}$ (Table 1). FAB-MS $m / z 569.1[\mathrm{M}+\mathrm{H}]^{+}$. High-resolution FAB-MS $m / z$ $569.1436[\mathrm{M}+\mathrm{H}]^{+}\left(\right.$Calcd for $\left.\mathrm{C}_{32} \mathrm{H}_{24} \mathrm{O}_{10}: 569.1448\right)$.

Isoginkgetin (6): A pale-yellow power, FAB-MS m/z: $567.1[\mathrm{M}+\mathrm{H}]^{+}$; The spectral data were compared with the published data. ${ }^{23)}$

Cell Culture Primary skin cells, HEMn (Cascade Biologics Inc., Port- land, Ore, U.S.A.), from neonatal foreskin were cultured in Medium 254 (Cascade Biologics) supplemented with Human Melanocyte Growth Supplement (HMGS, Cascade Biologics).

MTT Assay for Cell Viability Cells were plated at $1 \times 10^{5} /$ well (24-well plates). Twenty-four hours after plating, test samples were added and cultures were incubated for an additional $24 \mathrm{~h}$. Viability was determined using the MTT method, a colorimetric assay involving formation of purple formazan by mitochondrial dehydrogenase of active mitochondria. Cell viability was calculated according to the equation:

cell viability

$=$ absorbance (sample tested)/absorbance (medium only) $\times 100 \%$

Assay of Cellular Tyrosinase Activity Tyrosinase activity was measured as described previously with minor modifications. ${ }^{34)}$ HEMn cells were cultured in 24-well plates. After treatment with individual test samples for $24 \mathrm{~h}$, the cells were washed with phosphate-buffered saline (PBS) and lyzed with phosphate buffer, $\mathrm{pH} 6.8$, containing $1 \%$ Triton X-100. The cells were disrupted by freezing and thawing, and lysates were clarified by centrifugation at $10000 \boldsymbol{g}$ for $10 \mathrm{~min}$. After determination of protein content with a Bio-Rad protein assay kit, lysates were adjusted with lysis buffer to contain equal amounts of protein $(40 \mu \mathrm{g})$. These lysates were then added to wells (96-well plates) containing $2.5 \mathrm{~mm} l$-DOPA in $0.1 \mathrm{~m}$ phosphate buffer, $\mathrm{pH}$ 6.8. After incubation at $37^{\circ} \mathrm{C}$ for $1 \mathrm{~h}$, the absorbance of samples was measured at $475 \mathrm{~nm}$ using an ELISA reader. Tyrosinase inhibitory activity was calculated with the following formula:

tyrosinase inhibition (\%)

$=\left[1-\left(\right.\right.$ O.D. $_{475}$ of sample $/$ O.D. ${ }_{475}$ of control $\left.)\right] \times 100 \%$

Measurement of Melanin Content of Melanocytes Melanin contents were measured as described previously with slight modifications. ${ }^{34)}$ Briefly, cells were treated with tested individual samples for $24 \mathrm{~h}$. Cell pellets were dissolved in $1 \mathrm{~N} \mathrm{NaOH}$ at $37^{\circ} \mathrm{C}$ overnight and centrifuged for $10 \mathrm{~min}$ at $10000 \mathrm{~g}$. The optical density (O.D.) of each supernatant was measured at $450 \mathrm{~nm}$ using an ELISA reader.

Western Blot Analysis of the Tyrosinase-Related Proteins Western blot analysis was performed as described previously to determine the expression of tyrosinase and TRPs. ${ }^{35)}$ Cells $\left(1 \times 10^{6} /\right.$ well $)$ were lyzed with PBS containing 1\% Triton X-100, 1 mm phenylmethylsulfonyl fluoride (PMSF), $1 \mathrm{mg} / \mathrm{ml}$ aprotinin, and $10 \mathrm{mg} / \mathrm{ml}$ leupeptin, and lysates were subjected to centrifugation at $12000 \mathrm{~g}$ for $10 \mathrm{~min}$. The total protein content of each supernatant was determined with a Bio-Rad protein assay kit. Equal amount protein content of each sample was added to SDS sample buffer, and proteins were separated by polyacrylamide gel $(10 \%)$ electrophoresis. Following electrotransfer to PVDF membranes (Immobilon-P, Millipore Corp., Bedford, Mass, U.S.A.), the membranes were incubated overnight with PBS containing $5 \%$ non-fat dry milk, $0.1 \%$ Tween 20 and $0.1 \% \mathrm{NaN}_{3}$. Anti-tyrosinase (C-19), anti-TRP-1 (G-17), and anti-TRP-2 (D-18) antibodies (Santa Cruz Biotechnology Inc., Europe) were added at a 1:1000 dilution, and membranes were incubated at room temperature for $3 \mathrm{~h}$. After extensive washes, the blots were incubated for $2 \mathrm{~h}$ at room temperature with alkaline phosphatase-conjugated anti-goat IgG (Santa Cruz Biotechnology) diluted $1: 5000$ in PBS containing 5\% non-fat dry milk, $0.1 \%$ Tween 20 , and $0.1 \%$ $\mathrm{NaN}_{3}$. After washing, protein-bound alkaline phosphatase activity was detected with NBT/5-bromo-4-chloro-3-indolyl phosphate (BCIP) substrate. The extent of protein loading was evaluated by Western blotting with an antibody to $\beta$-actin.

RNA Extraction and Reverse Transcription Total RNA was extracted using the High Pure RNA Isolation Kit (Roche Molecular Biochemicals, Mannheim, Germany). The quality of the total RNA sample was evaluated by determination of the $\mathrm{OD}_{260} / \mathrm{OD}_{280}$ ratio. To prepare a cDNA pool from each RNA sample, total RNA $(1 \mu \mathrm{g})$ was reverse-transcribed using the Transcriptor First Strand cDNA Synthesis Kit (Roche Molecular Biochemicals) according to the manufacturer's instructions. Each cDNA pool was stored at $-20{ }^{\circ} \mathrm{C}$ until real-time PCR analysis was performed.

PCR Primers The specific oligonucleotide primer pairs used for quantitative real-time PCR (q-RT PCR) were selected from the Roche Universal ProbeLibrary. The sequences of the proper primers are as follows: TYR, forward primer: $5^{\prime}$-CATTCTTCTCCTCTTGGCAGA-3', reverse primer: $5^{\prime}$ CCGCTATCCCAGTAAGTGGA-3'; TYRP1, forward primer: GCTTTTCTCACATGGCACAG, reverse primer: GGCTCTTGCAACATTTCCTG; TYRP2, forward primer: CGACTCTGATTAGTCGGAACTCA, reverse primer: GGTGGTTGTAGTCATCCAAGC; GAPDH, forward primer: AGCCACATCGCTCAGACAC, reverse primer: GCCCAATACGACCAAATCC.

Quantitative Real-Time PCR (qRT PCR) Assay for Tyrosinase-Re- 
lated Genes Quantitative real-time PCR reactions were performed on the Roche LightCycler Instrument 2.0 using LightCycler ${ }^{\circledR}$ TaqMan Master (Roche Molecular Biochemicals). The ProbeFinder software (www.universalprobelibrary.com) was used to design the optimal assay, which involved the respective labeled probes of the Universal ProbeLibrary Set and the human and gene-specific primers. The data of each RT-PCR experiment were automatically analyzed and an amplification plot was generated for each cDNA sample. From each of these plots, the LightCycler 4 Data analysis software automatically calculates the CP value (crossing point: the turning point corresponds to the first maximum of the second derivative curve) which indicates the beginning of exponential amplification. The mRNA level was normalized with reference to the amount of a housekeeping gene transcript (GAPDH mRNA).

Statistical Analysis Differences between the groups were tested for significance by means of the non-parametric Mann-Whitney $U$-test. A $p$-value $<0.05$ was considered to indicate statistical significance.

Acknowledgments This study was supported by a grant from the Taiwan Salt industrial corporation. We are grateful to Shwu-Huey Wang (Instrumentation Center of Taipei Medical University) and Shou-Ling Huang (Nuclear Magnetic Resonance Lab, Instrumentation Center College of Science, National Taiwan University) for the NMR data acquisition, Shu-Yun Sun for HR-FAB-MS measurements in the Instrumentation Center of the College of Science, National Taiwan University, and to Prof. Shoei-Sheng Lee for recording circular dichroism data (School of Pharmacy, College of Medicine, National Taiwan University). We also express our gratitude to the Juridical Person of the Yen Foundation, Taiwan, for supporting this study.

\section{References}

1) Nordlund J. J., Boissy R. E., Hearing V. J., King R. A., Ortonne J. P., "The Pigmentary System," Oxford University Press, New York, 1998.

2) Park H. Y., Lee J., Gonzalez S., Middelkamp-Hup M. A., Kapasi S., Peterson S., Gilchrest B. A., J. Invest. Dermatol., 122, 159-166 (2004).

3) Chen Q. X., Kubo I., J. Agric. Food Chem., 50, 4108-4112 (2002).

4) Yokochi N., Morita T., Yagi T., J. Agric. Food Chem., 51, 2733-2736 (2003).

5) Tripathi R. K., Hearing V. J., Urabe K., Aroca P., Spritz R. A., J. Biol. Chem., 267, 23707-23712 (1992).

6) Maeda K., Yokokawa Y., Hatao M., Naganuma M., Tomita Y., J. Dermatol. Sci., 14, 199-206 (1997).

7) Park S. H., Kim D. S., Kim W. G., Ryoo I. J., Lee D. H., Huh C. H., Youn S. W., Yoo I. D., Park K. C., Cell. Mol. Life Sci., 61, 2878-2885 (2004).

8) Sturm R. A., Box N. F., Ramsay M., Bioessays, 20, 712-721 (1998).

9) Hirobe T., Pigment Cell Res., 18, 2-12 (2005).

10) Jones K., Hughes J., Hong M., Jia Q., Orndorff S., Pigment Cell Res.,
15, 335-340 (2002).

11) Hudgins J. W., Christiansen E., Franceschi V. R., Tree Physio., 24, $251-264$ (2004).

12) Ohmoto Y., Ohgi T., Koganei N., Chem. Pharm. Bull., 28, 1894-1899 (1980).

13) Hayashi Y., Kim Y., Biosci. Biotechnol. Biochem., 56, 1302-1303 (1992).

14) Xuan L. J., Xu Y. M., Fang S. D., Phytochemistry, 39, 1143-1145 (1995).

15) Kubo I., Ying B. P., Phytochemistry, 30, 3475-3477 (1991).

16) Cambie R. C., Cox R. E., Sidwell D., Phytochemistry, 23, 333-336 (1984).

17) Hayashi Y., Matsumoto T., Nishizawa M., Togami M., Hyono T., Nishikawa N., Uemura M., Sakan T., J. Org. Chem., 47, 3421-3428 (1982).

18) Shrestha K., Banskota A. H., Kodata S., Shrivastava S. P., Strobel G., Gewali M. B., Phytomedicine, 8, 489-491 (2001).

19) Qi S. H., Wu D. G., Ma Y. B., Luo X. D., Acta Bot. Sin., 45, 11291133 (2003).

20) Agrawal P. K., "Carbon-13 NMR of Flavonoids," Elsevier, Amsterdam, 1989.

21) Krauze-Baranowska M., Sowinski P., Planta Med., 65, 482-484 (1999).

22) Li S. H., Zhang H. J., Niu X. M., Yao P., Sun H. D., Fong H. H., J. Nat. Prod., 66, 1002-1005 (2003).

23) Sheppard K., Phytochemistry, 26, 3335-3337 (1987)

24) Das B., Mahender G., Koteswara Rao Y., Prabhakar A., Jagadeesh B., Chem. Pharm. Bull., 53, 135-136 (2005).

25) Slade D., Ferreira D., Marais J. P., Phytochemistry, 66, 2177-2215 (2005).

26) Briganti S., Camera E., Picardo M., Pigment Cell Res., 16, 101-110 (2003).

27) Wang K. H., Lin R. D., Hsu F. L., Huang Y. H., Chang H. C., Huang C. Y., Lee M. H., J. Ethnopharmacol., 106, 353-359 (2006).

28) Houghton A. N., J. Exp. Med., 180, 1-4 (1994).

29) Li C. Y., Gao T. W., Wang G., Han Z. Y., Shen Z., Li T. H., Liu Y. F., Br. J. Dermatol., 150, 1081-1090 (2004).

30) Vijayasaradhi S., Doskoch P. M., Houghton A. N., Exp. Cell Res., 196 233-240 (1991).

31) Widlund H. R., Fisher D. E., Oncogene, 22, 3035-3041 (2003).

32) Pak B. J., Chu W., Lu S. J., Kerbel R. S., Ben-David Y., Cancer Metastasis Rev., 20, 27-32 (2001).

33) Hearing V. J., J. Dermatol. Sci., 37, 3-14 (2005).

34) Nagata H., Takekoshi S., Takeyama R., Homma T., Yoshiyuki Osamura R., Pigment Cell Res., 17, 66-73 (2004).

35) Lee J. Y., Kang W. H., Pigment Cell Res., 16, 504-508 (2003). 